\title{
КОЕФІЦІЕНТИ ФЕНОТИПОВОЇ КОНСОЛІДАЦІЇ ІНДЕКСУ СІВЯС СВИНОМАТОК УЕЛЬСЬКОЇ ПОРОДИ
}

\author{
Церенюк Олександр Миколайович \\ доктор сільськогосподарських наук, доцент \\ Інститут тваринництва НААН \\ ORCID: 0000-0003-4797-9685 \\ Email: tserenyuk@gmail.com
}

Мартинюк Ірина Миколаївна кандидат сільськогосподарських наук, ст. науковий співробітник Інститут тваринництва НАAН ORCID: 0000-0002-3675-124X Email: martinyuk.i.n.2015@gmail.com Акімов Олександр Валентинович
кандидат сільськогосподарських наук, ст. науковий співробітник
Інститут тваринництва HAAH
ORCID: 0000-0002-1938-0459
Email: akimov.kharkiv@gmail.com

Вечорка Вікторія Вікторівна доктор сільськогосподарських наук, професор Сумський національний аграрний університет ORCID: 0000-0003-4956-2074 E-mail: vvvechorka@gmail.com

Метою досліджень, результати якої викладені у статті, було вивчення впливу віку свиноматок і кнурів на їх показники індексу СІВЯС із урахуванням сезону року та віку тварин. Дослідження проводилися в дослідному господарстві ДП ДГ „Гонтарівка” Вовчанського району Харківської області. Для відтворення поголів'я у господарстві використовують природне парування свиноматок. Осіменіння свиноматок було проведено згідно зі схемою досліджень. Для проведення експериментальної роботи на свинофермі племзаводу було відібрано 35 голів основних свиноматок та 4 кнури породи уельс різного віку та різної живої ваги. Було сфрормовано чотири групи маток. 3 метою вивчення впливу сезону року на показники індексу СІВЯС свиноматок, першу серію досліджень провели восени, другій серію - навесні за тією ж схемою. Використовували у обох серіях досліджень одних і тих самих тварин. По різних групах тварин індекс СІВЯС коливався 8 межах від 93,88 до 98,41 балів. Хоча й не було отримано вірогідних розбіжностей між групами за індексом СІВяС, вірогідні відмінності були отримані за абсолютними показниками. Краща група перевершувала рівень багатоплідності гіршої групи на $11,55 \%(p<0,05)$. Враховуючи те, що індекс $є$ комплексним показником, що характеризує загальний рівень відтворної здатності свиноматок, значення показників живої маси при відлученні, враховуючи молочність свиноматок, в певній мірі нівелювали розбіжності між групами. Та разом із тим, всього чотири групи перевершували середні значення по всім групам. Ці групи були сфрормовані із маток різного віку. Їх об'єднувало те, що вони були осемінені більш віковими кнурами. В межах окремих серій досліджень, кращі значення багатоплідності також були отримані за використання цих кнурів. Саме це, за достатньо вирівняної маси гнізд при відлученні, було визначальним фактором за розрахунку індексу СІВЯС. Більш консолідовані значення показнику індексу СІВЯС були за літніх опоросів. В межах вікових періодів найменш консолідованим рівнем показника індексу CIBЯC в період зимових опоросів відзначались матки у віці 18 міс. за їх осіменіння кнурами того ж віку. В період літніх опоросів - вікові матки за їх осіменіння віковими кнурами. Натомість найбільш консолідованими в період зимових опоросів були матки молодші матки з кнурами у віці 24 та 48 міс. В літній же період найбільш консолідованими були матки молодші матки за їх осіменіння віковими кнурами.

Ключові слова: свинарство, технологія, свиноматки, відтворна здатність, індекс СІВЯС, коефріцієнти френотипової консолідації, сезони року, вік тварин.

DOI: https://doi.org/10.32845/bsnau.lvst.2020.2.14.

Постановка проблеми. Свинарство $€$ одною 3 провідних галузей тваринництва від якої в значній мірі залежить вирішення питання забезпечення населення високоцінним білковим продуктом тваринного походження. Попит на продукти тваринництва значною мірою зумовлено зростанням чисельності населення, його платоспроможністю, що й спонукало до нарощення виробництва м'яса у світі за останні три десятиліття майже втричі. Така тенденція буде продовжуватися і надалі, оскільки попит зростає

саме на білкову продукцію тваринного походження [1-4] Нарощування виробництва ґрунтується на том, що в останні десятиріччя у вітчизняному тваринництві, і зокрема у свинарстві досягнуто значного прогресу [5-6]. Підвищення ефективності виробництва свинини відбувається за рахунок вдосконалення по окремих складових. Не є винятком і такий важливий елемент як відтворна здатність свиноматок [7-11]. У сучасному світовому свинарстві значного поширення набула індексна селекція, яка розкриває генетичну i Вісник Сумського національного аграрного університету 
біологічну сутність явищ високої продуктивності тварин та дає можливість визначити кращі породні поєднання [12].

Аналіз останніх досліджень і публікацій. Різні технології виробництва свинини спрямовані на отримання максимальної продуктивності від свиней. При цьому значна увага приділяється групі показників відтворної здатності свиноматок. Отже, при розроблені сучасних програм селекції суттєва увага зосереджується насамперед на покращенні відтворювальних ознак свиноматок [13-14].

Сучасні тенденції до зміни клімату потребують приділяти більше уваги до вивчення продуктивності свиноматок під впливом окремих паратипових факторів. Хоча й існує думка про відсутність такого впливу [15]. В той же час відтворна здатність свиноматок належить до ознак із низьким рівнем успадковування, вплив на яку паратипових факторів є значним [16-18].

Одним 3 головних показників, що характеризує відтворну здатність свиноматок $€$ багатоплідність свиноматок. Доведено наявність високих та позитивних кореляцій між кількістю поросят та масою гнізда як при народженні, так і при відлученні [19-22]. Зазвичай цей показник $€$ обов'язковим в конструкціях різних індексів, що призначені комплексно оцінювати відтворну здатність свиноматок.

Метою роботи було вивчення впливу віку свиноматок і кнурів на їх показники індексу CІВЯС із урахуванням сезону року та віку тварин.
Матеріали та методи досліджень. Дослідження проводилися в дослідному господарстві ДП ДГ „Гонтарівка” Вовчанського району Харківської області, на базі племінної ферми з утримання свиней породи уельс впродовж 20162017 років. Для відтворення поголів'я у господарстві використовують природне парування свиноматок. Проведені дослідження були продовженням робіт (Мартинюк І. М., Бугров О. Д., 2015 р.) [23], та (Церенюк О. М., Мартинюк І. М., Акімов О. В., Шкавро Н. М., Хмельничий Л. М., 2019) [24], розпочатих на цьому стаді, з вивченням більш широкого діапазону вікових поєднань кнурів і свиноматок та впливу сезону року на показник багатоплідність та його фенотипову консолідованість. Дослідження були проведені ґрунтуючись на традиційних підходах [25].

Осіменіння свиноматок було проведено згідно до схеми досліджень (табл. 1).

Для проведення експеріментальної роботи на свинофермі племзаводу було відібрано 35 голів основних свиноматок та 4 кнури породи уельс різного віку та різної живої ваги. Було сфрормовано чотири групи маток. 3 метою вивчення впливу сезону року на продуктивність свиноматок, першу серію досліджень провели восени, другій серію навесні за тією ж схемою. Використовували у обох серіях досліджень одних і тих самих тварин (як батьківську так і материнську складову).

\section{1. Схема досліджень}

\begin{tabular}{|c|c|c|c|c|c|}
\hline \multicolumn{2}{|c|}{ Перша серія (зимові опороси) } & \multicolumn{2}{|c|}{ Друга серія (літні опороси) } & \multicolumn{2}{c|}{ Вік тварин, міс } \\
\hline група тварин & кількість маток у групі, гол & група тварин & кількість маток у групі, гол & свиноматок & кнурів \\
\hline I & 9 & $\mathrm{~V}$ & 7 & 48 & 48 \\
\hline II & 9 & $\mathrm{VI}$ & 10 & 18 & 48 \\
\hline III & 8 & $\mathrm{VII}$ & 9 & 24 & 24 \\
\hline IV & 9 & $\mathrm{VIII}$ & 9 & 18 & 18 \\
\hline
\end{tabular}

Осіменіння маток проводилось двічі в одну охоту: перший раз через 18-20 годин після встановлення охоти, повторно - через 12-18 годин. В перший період поросності матки утримувались групами по 7-10 голів. За півтора місяця до опоросу свиноматки були розміщені по 4-5 голів у станку, а за тиждень до опоросу були переведені в індивідуальні станки. Протягом поросності матки піддослідних груп були поставлені в ідентичні умови годівлі, догляду та утримання.

Селекційний індекс відтворної здатності (відтворювальних якостей) свиноматок (СІВЯС), (Церенюк О.М., 2010) [26-27] визначали за формулою (1):

$$
\mathrm{CIBCC}=6 \mathrm{X}_{1}+9,34\left(\mathrm{X}_{2} / \mathrm{X}_{3}\right),
$$

де: СІВЯС - селекційний відтворної здатності (відтворювальних якостей) свиноматок;

$\mathrm{X}_{1}$ - багатоплідність, гол.;

$\mathrm{X}_{2}$ - маса гнізда при відлученні, кг;

$\mathrm{X}_{3}$ - доба відлучення, діб.

Оцінку ступеня фенотипової консолідації основних ознак продуктивності свиней проводили за Ю. П. Полупаном [28], до всієї оціненої групи тварин (по обом сезонам за різної живої маси) за формулами (2-3):

$$
\mathrm{K}_{1}=1-\frac{\sigma_{\Gamma}}{\sigma_{3}}
$$

Вісник Сумського національного аграрного університету

$$
\mathrm{K}_{2}=1-\frac{\mathrm{CV}_{\Gamma}}{\mathrm{CV}_{3}}
$$

де: К К $_{2}$ - ступінь фенотипової консолідованості оцінюваної групи;

$\sigma_{г}$ та $\mathrm{CV}_{r}$ - середньоквадратичне відхилення та коефіцієнт мінливості оцінюваної групи тварин за конкретною ознакою;

$\sigma_{3}$ та $\mathrm{Cv}_{3}$ - ті самі показники генеральної сукупності (корів усіх типів конституції).

Показники, отримані дослідним шляхом були опрацьовані методом варіаційної статистики [29-30], з використанням програмного забезпечення MS Excel.

Результати досліджень та їх обговорення. По різних групах тварин індекс СІВЯС коливався в межах від 93,88 до 98,41 балів (рис.). Хоча й не було отримано вірогідних розбіжностей між групами за індексом CІBЯC, вірогідні відмінності були отримані за абсолютними показниками. Краща група (матки у віці 18 міс. за зимових опоросів) перевершувала рівень багатоплідності гіршої групи (матки у віці 24 міс. за літніх опоросів) на 11,55\% ( $<<0,05)$. Враховуючи те, що індекс $є$ комплексним показником, що характеризує загальний рівень відтворної здатності свиноматок, значення показників живої маси при відлученні, враховуючи молочність свиноматок, в певній мірі нівелювали розбіжності між групами. Та разом із тим, всього чотири групи перевершували середні значення по всім групам. Ці групи були сформо- 
вані із маток різного віку, однак їх об'єднувало те, що вони були осімінені більш віковими кнурами (48 міс.). В межах окремих серій досліджень, кращі значення багатоплідності також були отримані за використання цих кнурів. Саме це, за достатньо вирівняної маси гнізд при відлученні, було визначальним фактором за розрахунку індексу CІВЯС, хоча й вага показника багатоплідності у індексі менша.

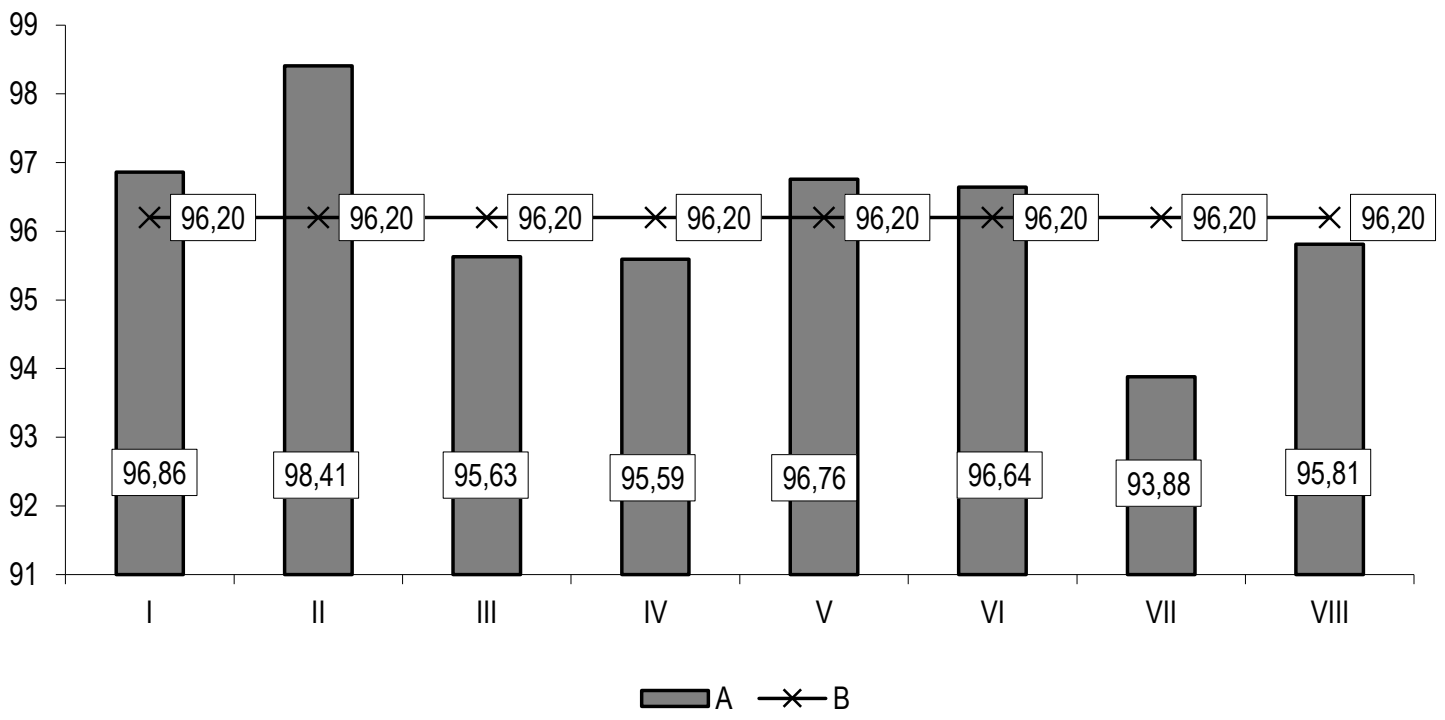

Показники індексу СІBЯС свиноматок

Після оцінки показнику індексу СІВЯС свиноматок були розраховані коефіцієнти фенотипової консолідації (табл.).

\begin{tabular}{|c|c|c|c|}
\hline \multirow[b]{2}{*}{ Групи } & \multirow[b]{2}{*}{$\mathrm{n}$, гол } & \multicolumn{2}{|c|}{ Багатоплідність,гол } \\
\hline & & $K_{1}$ & $\mathrm{~K}_{2}$ \\
\hline \multicolumn{4}{|c|}{ Зимові опороси } \\
\hline $\mathrm{I}$ & 9 & $-0,086$ & $-0,079$ \\
\hline II & 9 & $-0,066$ & $-0,042$ \\
\hline III & 8 & $-0,063$ & $-0,069$ \\
\hline IV & 9 & $-0,219$ & $-0,226$ \\
\hline \multicolumn{4}{|c|}{ Літні опороси } \\
\hline $\mathrm{V}$ & 7 & $-0,094$ & $-0,088$ \\
\hline $\mathrm{VI}$ & 10 & $+0,309$ & $+0,313$ \\
\hline VII & 9 & $+0,025$ & $+0,001$ \\
\hline VIII & 9 & $-0,052$ & $-0,056$ \\
\hline
\end{tabular}

Більш консолідовані значення показнику індексу CІВЯС були за літніх опоросів (за виключенням вікових маток (48 міс.) за їх осіменіння віковими кнурами (48 міс.)). B межах вікових періодів найменш консолідованим рівнем показника індексу CIBЯC в період зимових опоросів відзначались матки у віці 18 міс. за їх осіменіння кнурами того ж віку. В період літніх опоросів - вікові матки (48 міс.) за їх осіменіння віковими кнурами (48 міс.). Натомість найбільш консолідованими в період зимових опоросів були матки молодші матки з кнурами у віці 24 та 48 міс. В літній же період найбільш консолідованими були матки молодші матки за їх осіменіння віковими кнурами (48 міс.).
Висновки. Порівняно із встановленими вірогідними розбіжностями за показником багатоплідності між матками у віці 18 міс., за зимових опоросів відносно маток у віці 24 міс. за літніх опоросів на рівні $11,55 \%$ ( $<<0,05)$, за показниками індексу СІВЯС між різними групами свиноматок вірогідних розбіжностей встановлено не було.

Виявлено вищий рівень консолідованості у маток різних варіантів поєднань за показниками індексу CIBЯC за літніх опоросів у порівнянні з матками різних варіантів поєднань за зимових опоросів. Виключення становила група маток (48 міс.) за їх осіменіння віковими кнурами (48 міс.).

\section{Список використаної літератури:}

1.Жукорський О.М., Никифорук О.В. Галузь свинарства - реальна та прогнозована загроза для довкілля. Агроекологічний журнал. 2013. №. 3, С. 102-107.

2.McIntyre B.D., Herren H.R., Wakhungu J., Watson R.T. Synthesis Report. International Assessment of Agricultural Knowledge, Science and Technology for Development (IAASTD). Washington: Island Press, 2009. 106 p.

3.Schneider Uwe A., Pushpam K. Greenhouse gas emission mitigation through agriculture [Електронний ресурс]. Choices. 2008. Vol. 23. Issue 1. Режим доступу: http:// purl.umn.edu/94500 
4.Mekonnen M.M., Hoekstra A.Y. The green, blue and grey water footprint of farm animals and animal products [Електронний ресурс] Value of Water Res. Rep. Ser. - UNESCO-IHE, Delft. The Netherlands. 2010. №. 48, Режим доступу: http://www. unesco-ihe.org/Value-of-water-reserach-reportseries/Research_Papers

5. Hladiy M.V., Polupan Y.P., Kovtun S.I., Kuzebnij S.V., Vyshnevskiy L.V., Kopylov K.V., Shcherbak O.V. Scientific and organizational aspects of generation, genetics, reproduction biotechnology and protection of the genofonds in livestock breeding. Animal Breeding and Genetics, 2018. №56, P. 5-14. doi: 10.31073/abg.56.01.

6. Vashchenko 0 . Combinational ability of specialized breeds and types of pigs in industrial crossbreeding. Animal Breeding and Genetics, 2017. №53, P. 84-90. doi: 10.31073/abg.53.11 [in Ukrainian].

7. Храмкова О.М. Відтворювальні якості свиноматок за різних поєднань порід і типів. Theoretical and Applied Veterinary Medicine. 2019. №7(2), C. 115-119. DOI 10.32819/2019.71021.

8. Церенюк О.М., Акімов О. В., Шкавро Н. В., Череута Ю. В. Індекси будови тіла двопородних ремонтних свинок та свиноматок. Науково-технічний бюлетень IT HАAH. 2019. №122, C. 248-257. DOI 10.32900/2312-8402-2019-122-248-257.

9. Мартинюк І.М., Церенюк О.М., Акімов О.В. Заплідненість та багатоплідність свиноматок залежно від кратності осіменіння у різні пори року. Науково-технічний бюлетень IT HАAH. 2019. №121, C. 156-162. DOI 10.32900/2312-8402-2019121-156-162.

10. Tsereniuk O., Susol R., Bordun O., Paliy A., Shkromada O., Akimov O., Tsereniuk M., Dependence of sows` phenotypic consolidation of productivity on the reason of their culling due in index selection. Porc Res. 2019. №9(1), P. 15-20.

11. Tsereniuk O., Tsereniuk M., Akimov O., Paliy A., Nanka O., Shkromada O., Pomitun I., Dependence of sows' productivity on the reason of their culling, in index selection. Porc Res. 2018. №8 (1), P. 17-23.

12. Вербич, І. В., Братковська, Г.В.Селекційне удосконалення племінних та продуктивних якостей свиней за допомогою оціночних індексів. Свинарство. 2019. №73, С. 166-172.

13. Hanenberg E.H.A.T., Knol E.F., \& Merks J.W.M. Estimates of genetic parameters for reproduction traits at different parities in Dutch Landrace pigs. Livestock Production Science, 2001. №69(2), P. 179-186. DOI 10.1016/S0301-6226(00)00258-X

14. Крамаренко С.С., Крамаренко О.С., Луговий С.І., Лихач А.В., Лихач В.Я. Аналіз головних компонент (РСА) ознак відтворення свиноматок великої білої породи. Вісник аграрної науки Причорномор'я. 2019. Вип. 2, C. 75-81. DOI 10.31521/2313-092X/2019-2(102)

15. Копитець Н.Г. Сучасний стан та тенденції розвитку ринку свинини в Україні Економіка АПК. 2018. №. 11, С. $44-54$. DOI https://doi.org/10.32317/2221-1055.201811044

16. Рукавиця А.А. Аналіз впливу використання селекційних (оціночних) індексів у якості критеріїв відбору на відтворювальні якості свиноматок української м'ясної породи. Науково-технічний бюлетень IT НААН. 2016. №115, С. $195-202$.

17. Церенюк О.М., Хватов А.І., Стрижак Т.А., Коваленко В.П. Об'єктивна оцінка материнської продуктивності свиней. Таврійський науковий вісник, 2010. Вып.69, С. 112-126.

18. Коваленко Т.С., Сурженко М.В. Вивчення типів успадкування полігенних ознак продуктивності свиней. Вісник Сумського національного аграрного університету. Серія: Тваринництво. 2013. №. 1, С. 76-78.

19. Young L.D., Pumfrey R.A., Cunningham P.J., \& Zimmerman D.R. Heritabilities and genetic and phenotypic correlations for prebreeding traits, reproductive traits and principal components. Journal of Animal Science, 1978. № 46(4), P. 937-949. DOI 10.2527/jas1978.464937x

20. Fahmy M.H., \& Bernard C.S. Interrelations between some reproductive traits in swine. Canadian Journal of Animal Science. 1972. № 52(1), P. 39-45. DOI 10.4141/cjas72-004

21. Biensen N.J., Haussmann M.F., Lay D.C., Christian L.L., \& Ford S.P. The relationship between placental and piglet birth weights and growth traits. Animal Scienc. 1999. №68(4), P. 709-715. DOI 10.1017/S1357729800050736

22. Крамаренко С.С., Луговий С.І., Лихач А.В., Крамаренко О.С., Лихач В.Я., Крамаренко С.С., Крамаренко А.С. Порівняльний аналіз відтворювальних ознак та кластерний аналіз свиней різних порід. Науковий вісник ЛНУВМБ імені С.З. Ґжицького, 2018, т 20, № 84, С. 21-26. DOI 10.15421/nvlvet8404

23. Мартинюк І.М., Бугров О.Д. Вплив віку свиноматок і кнурів породи уельс і українська м'ясна на вихід поросят в гнізді. Міжвід. тем. наук. Збірник Інституту свинарства і АПВ НААН Свинарство, 2015. Вип. 67, С. 103-106.

24. Церенюк О. М., Мартинюк І. М., Акімов О. В., Шкавро Н. М., Хмельничий Л. М. Коефіцієнти фенотипової консолідації показнику багатоплідності свиноматок уельської породи. Вісник Сумського національного аграрного університету Серія «Тваринництво». 2019. № 1-2 (36-37), 102-107. DOI 10.32845/bsnau.Ivst.2019.1-2.15

25. Методологія та організація наукових досліджень у тваринництві : посіб. / за ред. І.І. Ібатулліна, О.М. Жукорського. Київ: Аграр. наука. 2017. 328 с.

26. Церенюк О. М. Патент на корисну модель № 100641 Україна, МПК А01К 67/02 Спосіб відбору свиноматок. Інститут тваринництва НААН. № u 201411117; заявл. 13.10.2014; опубл. 10.08.2015. Бюл. №15. 3 с.

27. Полупан Ю.П. Оценка степени фенотипической консолидации генеалогических групп животных. Зоотехнія. 1996. №10, С. 13-15.

28. Плохинский Н.А. Руководство по биометрии для зоотехников. М.: Колос, 1969. 352 с. 2017. 228 c.

29. Барановский Д.И., Хохлов А.М., Гетманец О.М. Биометрия в MS Excel: учеб. пособ. Харків: ФЛП Бровин А. В.,

\section{References:}

1.Zhukors'kyy, O.M. and Nykyforuk, O.V., 2013. Haluz' svynarstva - real'na ta prohnozovana zahroza dlya dovkillya [The pig breeding industry - a real and predicted threat to the environment]. Ahroekolohichnyy zhurnal, issue 3, pp. 102-107. 
2.McIntyre, B.D., Herren, H.R., Wakhungu J., and Watson R.T., 2009. Synthesis Report. International Assessment of Agricultural Knowledge, Science and Technology for Development (IAASTD). Washington: Island Press, 106.

3. Schneider, Uwe A. and Pushpam, K., 2008. Greenhouse gas emission mitigation through agriculture [online] Choices. vol. 23, issue 1. Available at: http:// purl.umn.edu/94500 [Accessed 01 December 2019].

4. Mekonnen, M.M. and Hoekstra, A.Y., 2010. The green, blue and grey water footprint of farm animals and animal products [online]. Value of Water Res. Rep. Ser. - UNESCO-IHE, Delft. - The Netherlands. no. 48. Available at: http://www. unescoihe.org/Value-of-water-reserach-reportseries/Research_Papers [Accessed 01 December 2019].

5. Hladiy, M. V., Polupan, Y. P., Kovtun, S. I., Kuzebnij, S. V., Vyshnevskiy, L. V., Kopylov, K.V. and Shcherbak O. V., 2018. Scientific and organizational aspects of generation, genetics, reproduction biotechnology and protection of the genofonds in livestock breeding. Animal Breeding and Genetics, no. 56, pp. 5-14. doi: 10.31073/abg.56.01.

6. Vashchenko, $0 ., 2017$. Combinational ability of specialized breeds and types of pigs in industrial crossbreeding. Animal Breeding and Genetics, no. 53, pp. 84-90. doi: 10.31073/abg.53.11.

7. Khramkova, O. M., 2019. Vidtvoryuval'ni yakosti svynomatok za riznykh poyednan` porid i typiv [Reproductive qualities of sows in different combinations of breeds and types]. Theoretical and Applied Veterinary Medicine, no. 7(2), pp. 115-119. DOI 10.32819/2019.71021.

8. Tsereniuk, O. M., Akimov, O. V., Shkavro, N. V. and Chereuta, Yu.V., 2019. Indeksy budovy tila dvoporodnykh remontnykh svynok ta svynomatok [Body structure indices for two-offspring pigs and sows.]. Naukovo-tekhnichnyy byuleten' IT NAAN, no. 122, pp. 248-257. DOI 10.32900/2312-8402-2019-122-248-257.

9. Martinyuk, I. M., Tsereniuk, O. M. and Akimov, O. V., 2019 Zaplidnenist' ta bahatoplidnist' svynomatok zalezhno vid kratnosti osimeninnya u rizni pory roku [Fertilization and multiplicity of sows depending on the frequency of insemination at different times of the year]. Naukovo-tekhnichnyy byuleten' IT NAAN, no.121, pp. 156-162. DOI 10.32900/2312-8402-2019-121-156-162.

10. Tsereniuk, O., Susol, R., Bordun, O., Paliy, A., Shkromada, O., Akimov, O. and Tsereniuk, M., 2019. Dependence of sows' phenotypic consolidation of productivity on the reason of their culling due in index selection. Porc Res, no. 9(1), pp. 15-20.

11. Tsereniuk, O., Tsereniuk, M., Akimov, O., Paliy, A., Nanka, O., Shkromada, O. and Pomitun, I., 2018. Dependence of sows' productivity on the reason of their culling, in index selection. Porc Res. no. 8 (1), pp. 17-23.

12. Verbych, I. V. and Bratkovs'ka, G. V., 2019. Selekcijne udoskonalennja pleminnyh ta produktyvnyh jakostej svynej za dopomogoju ocinochnyh indeksiv. [Selection improvement of breeding and productive qualities of pigs with the help of evaluation indices]. Svynarstvo, (73), 166-172.

13. Hanenberg, E. H. A. T., Knol, E. F. and Merks, J. W. M., 2001. Estimates of genetic parameters for reproduction traits at different parities in Dutch Landrace pigs. Livestock Production Science, no. 69(2), pp. 179-186. DOI 10.1016/S0301-6226(00)00258$X$

14. Kramarenko, S. S., Kramarenko, O. S., Luhovyy, S. I., Lykhach, A. V. and Lykhach, V. Y. A., 2019. Analiz holovnykh komponent (PCA) oznak vidtvorennya svynomatok velykoyi biloyi porody [Principal Component Analysis (PCA) of sows reproduction of Large White breed]. Visnyk ahrarnoyi nauky Prychornomor'ya, no. 2, pp. 75-81. DOI 10.31521/2313-092X/2019-2(102).

15. Kopytets', N. H., 2018. Suchasnyy stan ta tendentsiyi rozvytku rynku svynyny v Ukrayini [The current state and tendencies of pork market development in Ukraine]. Ekonomika APK, no. 11, pp. 44-54. DOI https://doi.org/10.32317/22211055.201811044.

16. Rukavytsya, A.A., 2016. Analiz vplyvu vykorystannya selektsiynykh (otsinochnykh) indeksiv u yakosti kryteriyiv vidboru na vidtvoryuval'ni yakosti svynomatok ukrayins'koyi m'yasnoyi porody [Analysis of the influence of the use of breeding (evaluation) indices as selection criteria on reproductive qualities of sows of Ukrainian Meat breed]. Naukovo-tekhnichnyy byuleten' IT NAAN, no. 115, pp. 195-202.

17. Tsereniuk, O.M., Khvatov, A.l., Stryzhak, T.A. and Kovalenko, V.P., 2010. Ob'yektyvna otsinka materyns'koyi produktyvnosti svyney [Objective evaluation of maternal pig productivity]. Tavriys 'kyy naukovyy visnyk, no. 69, pp. 112-126.

18. Kovalenko, T. S. and Surzhenko, M. V., 2013 Vyvchennya typiv uspadkuvannya polihennykh oznak produktyvnosti svyney [Study of types of inheritance of polygenic features of pig productivity]. Visnyk Sums'koho natsional'noho ahrarnoho universytetu, Seriya: Tvarynnytstvo, no. 1, pp. 76-78.

19. Young, L. D., Pumfrey, R. A., Cunningham, P. J. and Zimmerman, D. R., 1978. Heritabilities and genetic and phenotypic correlations for prebreeding traits, reproductive traits and principal components. Journal of Animal Science, no. 46(4)., pp. 937-949. DOI 10.2527/jas1978.464937x

20. Fahmy, M. H. and Bernard, C. S., 1972. Interrelations between some reproductive traits in swine. Canadian Journal of Animal Science, no. 52(1), pp. 39-45. DOI 10.4141/cjas72-004.

21. Biensen, N. J., Haussmann, M. F., Lay, D. C., Christian, L. L. and Ford, S. P., 1999. The relationship between placental and piglet birth weights and growth traits. Animal Scienc., no. 68(4), pp. 709-715. DOI 10.1017/S1357729800050736

22. Kramarenko, S. S., Luhovyy, S. I., Lykhach, A. V., Kramarenko, O. S., Lykhach, V. Y. A., Kramarenko, S. S. and Kramarenko, A. S., 2018. Porivnyal'nyy analiz vidtvoryuval'nykh oznak ta klasternyy analiz svyney riznykh porid [Comparative analysis of reproductive traits and cluster analysis of pigs of different breeds]. Naukovyy visnyk LNUVMB imeni S. Z. Gzhyts'koho, vol. 20, no. 84, pp. 21-26. DOI 10.15421/nvlvet8404.

23. Martynyuk, I. M. and Buhrov O. D., 2015. Vplyv viku svynomatok i knuriv porody uel's i ukrayins'ka m'yasna na vykhid porosyat $v$ hnizdi [Influence of the age of sows and boars of the breed of Welsh and Ukrainian Meet on the output of piglets in the litter]. Mizhvid. tem. nauk. Zbirnyk Instytutu svynarstva i APV NAAN - Svynarstvo, no. 67, pp. 103-106.

24. Tsereniuk, O. M., Martynyuk, I. M., Akimov, O. V., Shkavro, N. V. and Khmelnichiy, L. M., 2019. Koeficijenty fenotypovoi' 
konsolidacii' pokaznyku bagatoplidnosti svynomatok uel's'koi' porody [Features of phenotypic consolidation of the indicator of high fertility of sows of the Uelian breed]. Visnyk Sums'kogo nacional'nogo agrarnogo universytetu Serija «Tvarynnyctvo».. no. 1-2 (3637). pp. 102-107. DOI 10.32845/bsnau.lvst.2019.1-2.15.

25. Ibatullin, I.,I., Zhukors`kyy, O.,M. ed., 2017 Metodolohiya ta orhanizatsiya naukovykh doslidzhen` u tvarynnytstvi: posib [Methodology and organization of scientific research in animal husbandry: a tool]. Kyiv: Ahrar. nauka.

26. Tsereniuk, O. M., 2015. Patent na korysnu model' № 100641 Ukrai'na, MPK A01K 67/02. Sposib vidboru svynomatok [Patent No. 100641 Ukraine, IPC A01K 67/02. How to select sows]. Instytut tvarynnyctva NAAN. № u 201411117. opubl. 10.08.2015. 15. 3 p.

27. Polupan, Yu. P., 1996. Otsenka stepeni fenotipicheskoy konsolidatsii genealogicheskikh grupp zhivotnykh [Assessment of the degree of phenotypic consolidation of genealogical groups of animals]. Zootekhníya, no. 10, pp. 13-15.

28. Plokhinskiy, N. A., 1969. Rukovodstvo po biometrii dlya zootekhnikov M. Kolos.

29. Baranovs'kiy, D. I., Khokhlov, A. M. and Getmanets, O. M., 2017. Biometriya v MS Excel : ucheb. posob. Kharkív FLP Brovin A. V.

\author{
Tsereniuk Alexander Nikolaevich, Doctor of Agricultural Sciences, Associate Professor, Institute of Animal Husbandry \\ NAAS \\ Martyniuk Iryna Mykolayivna, Ph.D. of Agricultural Sciences, Art. Researcher, Institute of Animal Husbandry NAAS \\ Akimov Alexander Valentinovich, Ph.D. of Agricultural Sciences, Art. Researcher, Institute of Animal Husbandry NAAS \\ (Kharkiv, Ukraine) \\ Ukraine) \\ Vechorka Victoria Viktorivna, Doctor of Agricultural Sciences, Professor, Sumy National Agrarian University (Sumy,
}

Coefficients of Welsh sows SIRQS-index phenotypic consolidation

The aim of the research, the results of which are presented in the article, was to study the influence of the age of sows and boars on their indicators of the SIRQS index, taking into account the season of the year and the age of the animals. The research was carried out in the experimental farm of SE Gontarivka, Vovchansky district, Kharkiv region. Natural mating of sows is used on the farm to reproduce the livestock. Insemination of sows was performed according to the study scheme. For the experimental work on the breeding farm, 35 heads of main sows and 4 Welsh boars of different ages and live weight were selected. Four groups of queens were formed. In order to study the impact of the season on the indicators of the SIRQS index of sows, the first series of studies was conducted in autumn, the second series - in the spring according to the same scheme. Used in both series of studies of the same animals. For different groups of animals, the SIRQS index ranged from 93.88 to 98.41 points. Although no significant differences were found between the groups according to the SIRQS index, significant differences were obtained in absolute terms. The best group exceeded the level of fertility of the worst group by $11.55 \%(p<0.05)$. Given that the index is a complex indicator that characterizes the overall level of reproductive capacity of sows, the values of live weight at weaning, taking into account the milk yield of sows, to some extent offset the differences between groups. At the same time, only four groups exceeded the average values for all groups. These groups were formed from queens of different ages. What they had in common was that they were inseminated with older boars. Within separate series of studies, the best values of fertility were also obtained using these boars. This, with a sufficiently balanced mass of nests during weaning, was the determining factor in calculating the SIRQS index. More consolidated values of the SIRQS index were for summer farrowing. Within the age periods, the least consolidated level of the SIRQS index during the winter farrowing period was observed in uteruses at the age of 18 months. for their insemination with boars of the same age. During the summer farrowing - age dams for their insemination with age boars. Instead, the most consolidated during the winter farrowing period were the uteruses of the younger uterus with boars at the age of 24 and 48 months. In the summer, the most consolidated were the uteruses of the younger uterus for their insemination with age-old boars.

Key words: pig breeding, technology, sows, reproductive capacity, multiplicity, coefficients of phenotype consolidation, seasons, age of animals.

Дата надходження до редакції: 09.09.2020 р. 